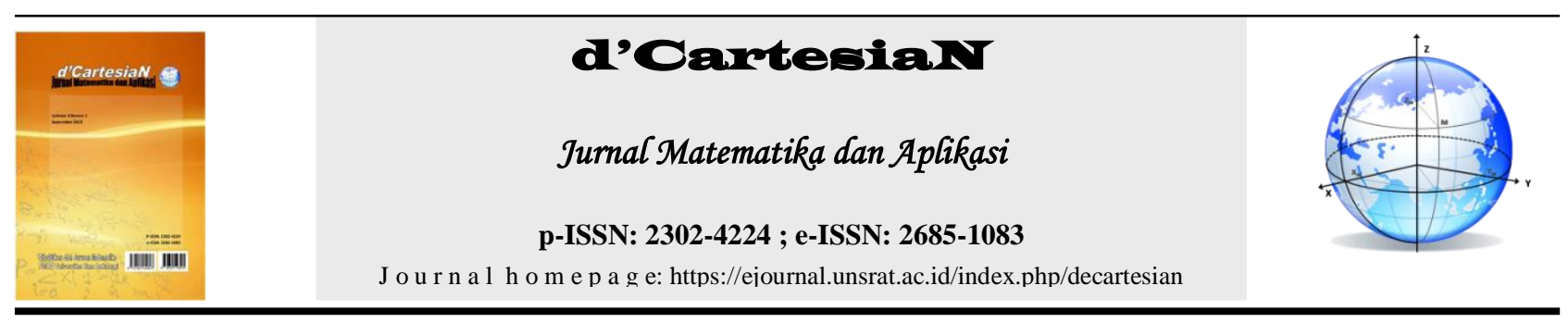

\title{
Penerapan Model Vector Autoregressive (VAR) Untuk Memprediksi Harga Cengkeh, Kopra, Dan Pala Di Sulawesi Utara
}

\author{
Yulin Tunang1, Tohap Manurung1, Nelson Nainggolan ${ }^{1 *}$ \\ ${ }^{1}$ Jurusan Matematika-Fakultas Matematika dan Ilmu Pengetahuan Alam-Universitas Sam Ratulangi Manado, Indonesia \\ ${ }^{*}$ Corressponding author : $\underline{n} \_$nelson@unsrat.ac.id
}

\begin{abstract}
A B S T RA K
Tujuan penelitian ini adalah menentukan model vector autoregressive (VAR) dari harga komoditas Cengkeh, Kopra dan Pala di Sulawesi Utara. Data yang digunakan adalah data harga bulanan cengkeh, kopra dan pala periode Januari 2015 sampai Maret 2019. Hasil penaksiran parameter untuk harga cengkeh diperoleh nilai taksiran parameter 0,$174 ; 0,260 ; 0,151$ sedangkan untuk harga kopra diperoleh nilai taksiran parameter 0,060; 0,004; 0,002; dan untuk harga pala diperoleh nilai taksiran parameter 0,215; 0,105; 0,625. Hasil prediksi bulan April, Mei dan Juni tahun 2019 yaitu pada bulan April 2019 harga cengkeh sebesar Rp90.882, harga kopra sebesar Rp4.461, dan harga pala sebesar Rp70.316. Hasil prediksi pada bulan Mei 2019 harga cengkeh sebesar Rp90.231, harga kopra sebesar Rp4.411, dan harga pala sebesar Rp70.021. Hasil prediksi pada bulan Juni 2019 harga cengkeh sebesar Rp89.392, harga kopra sebesar Rp4.356, dan harga pala sebesar Rp69.532.
\end{abstract}

\section{INFO ARTIKEL}

Diterima : 24 Juni 2019

Diterima setelah revisi : 23 Juli 2019

Tersedia online : 25 Juli 2019

\begin{abstract}
A B S T R A C T
The purpose of this study is to determine the vector autoregressive (VAR) model of the prices of clove, copra and nutmeg commodities in North Sulawesi. The data used are data on monthly prices of cloves, copra and nutmeg for the period of January 2015 to March 2019. Parameter estimation results for clove prices are estimated parameter values of 0,$174 ; 0,260 ; 0,151$ while for the copra price, the estimated value of the parameter is 0,060 ; 0,$004 ; 0,002$; and for nutmeg prices the parameter value of 0,215 is obtained; 0,105; 0,625. Prediction results for April, May and June 2019, namely in April 2019 the price of cloves was Rp90.882, the price of copra was Rp4.461, and the price of nutmeg was Rp70.316. The prediction results in May 2019 of clove prices amounted to Rp90.231, copra prices amounted to Rp4.411, and nutmeg prices were Rp70.021. Predicted results in June 2019 of clove prices amounted to Rp89.392, copra prices of Rp4.356, and nutmeg prices of Rp69.532.
\end{abstract}

\author{
ARTICLE INFO \\ Accepted : 24 June 2019 \\ Accepted after revision : 23 July 2019 \\ Available online : 25 July 2019 \\ Keywords: \\ Vector Autoregressive (VAR) model \\ Clove \\ Copra \\ Nutmeg
}

\section{PENDAHULUAN}

Indonesia merupakan negara yang memiliki sumber daya alam yang melimpah. Sumber daya alam tersebut dapat dikelola dengan baik dan menghasilkan sesuatu yang berharga bagi masyarakat Indonesia. Provinsi Sulawesi Utara memiliki potensi sumber daya alam yang besar dan bervariasi. Potensi Ekonomi Sulawesi Utara mencakup sektor pertanian (perkebunan dan peternakan), perikanan, dan industri parawisata. Berdasarkan potensi daerah yang ada dan masalah yang dihadapi, maka untuk pembangunan Sulawesi Utara diarahkan untuk terus meningkatkan sektor pertanian, yang meliputi cengkeh, pala, kelapa dan produksi perikanan, dan lain-lain [1].

Salah satu upaya untuk mengantisipasi terjadinya fluktuasi harga adalah dengan melakukan peramalan harga. Peramalan harga dimaksudkan untuk melakukan prediksi harga masa depan dalam kurun waktu tertentu, dengan hasil keluaran berupa harga masa depan. Peramalan merupakan pendugaan akan suatu hal dimasa yang akan datang, kebutuhan peramalan timbul karena adanya jeda waktu antara satu hal atau peristiwa dengan kebutuhan mendatang [2].

Analisis deret waktu yang mempunyai lebih dari dua variabel dapat menggunakan model Vector Autoregressive (VAR). Namun di dalam model VAR mempunyai syarat bahwa data yang digunakan harus bersifat stasioner. Jika data tidak stasioner maka akan dilakukan beberapa proses kestasioneran terlebih dahulu.

Dalam data yang dianalisis tidak selamanya menunjukkan kestasioneran, sebab data yang tidak stasioner seringkali didapati di kehidupan nyata. Time series yang rataannya tidak konstan termasuk tidak stasioner. Salah satu cara menstasionerkan data adalah melalui differencing (pembedaan). Proses Autoregressive Integrated Moving Average (ARIMA) adalah model time series [3]. 


\section{Pengertian Deret Waktu (Time Series)}

Deret waktu adalah serangkaian data yang diperoleh dari waktu ke waktu dengan selang waktu yang sama. Data dapat diakumulasi setiap menit, jam, hari, bahkan tahun.

Oleh karena itu, deret waktu yang diamati pada waktu $t_{1}, t_{2}, \ldots \ldots . t_{n}$ dapat dicatat sebagai $Y_{1}$, dengan $t$ merupakan urutan pengamatan yaitu $t=$ $1,2, \ldots \ldots \ldots . n$. Deret waktu dikatakan stasioner jika distribusi untuk $Y_{1}, Y_{2}, \ldots \ldots \ldots, Y_{n}$, adalah sama dengan $Y_{1+x}, Y_{2+x}, \ldots \ldots \ldots . . . Y_{n+x}$, dengan kata lain, mean, varian, dan kovarian dari deret waktu, yang stasioner adalah konstan untuk setiap waktu, atau dengan kata lain mean, varian, dan kovarian dari suatu deret waktu yang stasioner tidak dipengaruhi oleh waktu pengamatan [4].

\section{Kestasioneran}

Terdapat dua jenis kestasioneran, yaitu stasioner kuat dan stasioner lemah. Proses stokastik $\left\{Z_{t}\right\}$ dikatakan stasioner kuat (strickly stationary) jika distribusi gabungan dari $Z_{t 1}, Z_{t 2}, \ldots, Z_{t n}$ sama dengan distribusi gabungan dari $Z_{t 1-k}, Z_{t 2-k}, \ldots, Z_{t n-k}$, untuk semua $t_{1}, t_{2}, \ldots, t_{n}$ dan semua lag waktu $k$. Data yang tidak stasioner seringkali didapat dalam kehidupan nyata. Mengingat deret data yang digunakan dalam peramalan ARIMA adalah deret data yang variansi dan rata-ratanya telah stasioner maka untuk data yang tidak stasioner perlu dilakukan pembedaan (differencing) ataupun transformas [3].

\section{Fungsi Autokorelasi (ACF) dan PACF}

Dalam analisis deret waktu, fungsi autokovariansi, fungsi autokorelasi (ACF) dan fungsi autokorelasi parsial (PACF) merupakan hal penting untuk menentukan model dari data.

Tabel 1 adalah acuan yang digunakan untuk melihat model ACF dan PACF [3].

Tabel 1. Identifikasi Model Time Series AR(p),

\begin{tabular}{|c|c|c|c|}
\hline \multicolumn{4}{|c|}{ MA(q), dan ARMA(p,q) } \\
\hline & $\mathrm{AR}(\mathrm{p})$ & MA(q) & $\operatorname{ARMA}(p, q)$ \\
\hline $\mathrm{ACF}$ & $\begin{array}{l}\text { Ekponensial } \\
\text { menurun } \\
\text { mulai lag ke- } \\
\text { p. }\end{array}$ & $\begin{array}{l}\text { Terputus } \\
\text { (Cut-Off) } \\
\text { pada lag ke- } \\
\text { q, artinya } \\
\text { memotong } \\
\text { pada lag ke- } \\
\text { q, tetapi } \\
\text { setelah lag } \\
\text { ke-q tidak } \\
\text { memotong } \\
\text { lagi. }\end{array}$ & $\begin{array}{l}\text { Ekponensial } \\
\text { menurun } \\
\text { mulai lag } \\
\text { ke-p,q. }\end{array}$ \\
\hline PACF & $\begin{array}{l}\text { Terputus } \\
\text { (Cut-Off) } \\
\text { pada lag ke- } \\
\text { p, artinya } \\
\text { memotong } \\
\text { pada lag ke- } \\
\text { p, tetapi } \\
\text { setelah lag } \\
\text { ke-p tidak } \\
\text { memotong } \\
\text { lagi. }\end{array}$ & $\begin{array}{l}\text { Ekponensial } \\
\text { menurun } \\
\text { mulai lag ke- } \\
\text { q. }\end{array}$ & $\begin{array}{l}\text { Ekponensial } \\
\text { menurun } \\
\text { mulai lag } \\
\text { ke-p,q. }\end{array}$ \\
\hline
\end{tabular}

\section{Model Autoregressive (AR)}

Model Autoregressive (AR) adalah model yang menyatakan bahwa nilai pengamatan sekarang tergantung pada nilai pengamatan pada waktu-waktu sebelumnya dari dirinya sendiri ditambah dengan white noise [3].

Proses Autoregressive orde- $p$ ditulis dengan $\operatorname{AR}(p)$ adalah berbentuk:

$$
Z_{t}=\phi_{1} Z_{t-1}+\phi_{2} Z_{t-2}+\cdots+\phi_{p} Z_{t-p}+\varepsilon_{t}
$$

\section{Model Rata-rata Bergerak (MA)}

Proses Moving Average (MA) adalah suatu proses linear yang hakikatnya hanya sejumlah berhingga, yaitu:

$$
Z_{t}=\varepsilon_{t}-\theta_{1} \varepsilon_{t-1}-\cdots-\theta_{q} \varepsilon_{t-q}
$$

Model seperti ini dinamakan model Moving Average orde- $q$, ditulis $\mathrm{MA}(q)$. Jadi proses Moving Average adalah model yang mana nilai $Z_{t}$ bergantung pada suku-suku white noise waktu sekarang dan waktu-waktu sebelumnya [3].

\section{Model ARMA (Autoregressive Moving Average)}

Model ARMA (Autoregressive Moving Average) adalah campuran dari model $\operatorname{AR}(p)$ dan $\operatorname{MA}(q)$, sehingga memiliki asumsi bahwa data periode sekarang dipengaruhi oleh data pada periode sebelumnya [5]. Persamaan model ARMA $(p, q)$ dapat ditulis

$$
\begin{aligned}
Z_{t}= & \phi_{1} Z_{t-1}+\phi_{2} Z_{t-2}+\cdots+\phi_{p} Z_{t-p}+\varepsilon_{t}-\theta_{1} \varepsilon_{t-1}- \\
& \theta_{2} \varepsilon_{t-2}-\cdots-\theta_{q} \varepsilon_{t-q}
\end{aligned}
$$

\section{Model ARIMA}

Model time series yang digunakan berdasarkan asumsi bahwa data time series tersebut stasioner artinya rata-rata dan varians suatu data time series konstan. Tapi seperti diketahui bahwa banyak data time series dalam ilmu ekonomi adalah tidak stasioner, jika data time series tidak stasioner maka metode yang digunakan untuk membuat data stasioner yaitu dilakukan dengan differencing untuk data yang tidak stasioner dalam varians [6]. Menurut [3] dalam bukunya menjelaskan bahwa, secara umum persamaan model ARIMA adalah sebagai berikut:

$$
\begin{aligned}
W_{t}= & \phi_{1} W_{t-1}+\phi_{2} W_{t-2}+\cdots+\phi_{p} W_{t-p}+\varepsilon_{t}-\varepsilon_{t}- \\
& \theta_{1} \varepsilon_{t-1}-\cdots-\theta_{q} \varepsilon_{t-q}
\end{aligned}
$$

\section{White Noise}

Suatu contoh yang sangat penting dalam proses stasioner adalah proses yang dinamakan white noise, yang didefinisikan sebagai urutan dari variable acak yang independen (tidak saling bergantung) dan berdistribusi identic, disingkat dengan istilah i.i.d. Selanjutnya, [7] menjelaskan tentang proses white noise bahwa time series $\left\{\varepsilon_{t}\right\}$ dinamakan proses white noise apabila rangkaiannya marupakan variable acak yang independen dan berdistribusi identik, yang memenuhi:

$E\left(\varepsilon_{t}\right)=\mu_{\varepsilon}$ konstan (biasanya diasumsikan berharga nol)

$\gamma_{k}=E\left(Z_{t}-\mu\right)\left(Z_{t+k}-\mu\right)=0$ untuk semua $k \neq 0$
$\gamma_{(0)}=\sigma^{2}$ 


\section{Model Vector Autoregressive (VAR)}

Vector Autoregressive (VAR) dikemukakan pertama kali oleh C.A. Sims (1972). Vector Autoregressive (VAR) adalah suatu pendekatan peramalan kuantitatif yang biasanya diterapkan pada data Multivariat time series.

Menurut [3], Model vektor yang paling sederhana adalah model Vector Autoregressive (VAR). Misalkan $\boldsymbol{Z}_{t}$ adalah vektor time series stasioner lemah berdimensi $m$. Model VAR Orde-1, VAR(1), adalah berbentuk:

$\left(I-\Phi_{1} B\right) \boldsymbol{Z}_{t}=\varepsilon_{t} \quad$ atau $\quad \boldsymbol{Z}_{t}=\Phi_{1} \boldsymbol{Z}_{t-1}+\varepsilon_{t}$

dengan $\varepsilon_{t} \stackrel{\text { i.i.d }}{\sim} N(0 . \Sigma)$, dimana $\Sigma$ matriks $m \times m$, simetri, definit positif. Untuk proses white noise diasumsikan: $\Sigma=\sigma^{2} \boldsymbol{I}_{m}$. Secara khusus, untuk $m=3$, maka VAR(1) dapat dituliskan sebagai:

$Z_{1, t}=\phi_{11} Z_{1, t-1}+\phi_{12} Z_{2, t-1}+\phi_{13} Z_{3, t-1}+\varepsilon_{1, t}$

$Z_{2, t}=\phi_{21} Z_{1, t-1}+\phi_{22} Z_{2, t-1}+\phi_{23} Z_{3, t-1}+\varepsilon_{2, t}$

$Z_{3, t}=\phi_{31} Z_{1, t-1}+\phi_{32} Z_{2, t-1}+\phi_{33} Z_{3, t-1}+\varepsilon_{3, t}$

dalam bentuk matriks:

$\left(\begin{array}{l}Z_{1, t} \\ Z_{2, t} \\ Z_{3, t}\end{array}\right)=\left(\begin{array}{lll}\phi_{11} & \phi_{12} & \phi_{13} \\ \phi_{21} & \phi_{22} & \phi_{23} \\ \phi_{31} & \phi_{32} & \phi_{33}\end{array}\right)\left(\begin{array}{l}Z_{1, t-1} \\ Z_{2, t-1} \\ Z_{3, t-1}\end{array}\right)+\left(\begin{array}{l}\varepsilon_{1, t} \\ \varepsilon_{2, t} \\ \varepsilon_{3, t}\end{array}\right)$

$\left(\begin{array}{l}Z_{1, t} \\ Z_{2, t} \\ Z_{3, t}\end{array}\right)-\left(\begin{array}{lll}\phi_{11} & \phi_{12} & \phi_{13} \\ \phi_{21} & \phi_{22} & \phi_{23} \\ \phi_{31} & \phi_{32} & \phi_{33}\end{array}\right)\left(\begin{array}{l}Z_{1, t-1} \\ Z_{2, t-1} \\ Z_{3, t-1}\end{array}\right)=\left(\begin{array}{l}\varepsilon_{1, t} \\ \varepsilon_{2, t} \\ \varepsilon_{3, t}\end{array}\right)$

Proses VAR(1) stasioner apabila akar-akar dari persamaan $\left|I-\Phi_{1} B\right|=0$ terletak di luar lingkaran satuan. Misalkan $\lambda=B^{-1}$, maka

$\left|I-\Phi_{1} B\right|=0 \Leftrightarrow\left|\lambda I-\Phi_{1}\right|=0$

\section{Uji Diagnostik}

Uji diagnostik adalah untuk memastikan apakah model yang dipilih sudah baik atau belum, dengan menggunakan model sementara yang sementara dianggap paling cocok, maka nilai kesalahannya diselidiki. Jika pengujian diagnostik gagal maka tahapan identifikasi, penaksiran parameter, dan uji diagnostik diulang kembali. Hal ini dilakukan sampai sebuah model yang cocok atau yang baik diperoleh. Setelah terpilih model dengan nilai parameter yang sesuai, maka model tersebut sudah dapat digunakan untuk meramalkan data pada waktu yang akan datang. Apabila pada suatu saat pola data time series berubah, maka penaksiran parameter dilakukan kembali atau model yang baru dicari kembali [3].

\section{METODE PENELITIAN}

\subsection{Waktu Dan Tempat Penelitian}

Penelitian ini dilaksanakan mulai dari bulan Desember 2018 sampai bulan April 2019 di Laboratorium Komputer Dasar, Fakultas Matematika dan Ilmu Pengetahuan Alam, Universitas Sam Ratulangi Manado.

\subsection{Jenis Dan Sumber Data}

Data yang digunakan merupakan data sekunder harga komoditas yaitu Cengkeh, Kopra, dan Pala yaitu data periode bulan Januari 2015 sampai dengan bulan Maret 2019. Data bersumber dari Dinas Perindustrian Dan Perdagangan Daerah Provinsi Sulawesi Utara.

\subsection{Teknik Analisis Data}

Teknik analisis data akan digunakan dalam mengaplikasikan model Vector Autoregressive (VAR) pada penelitian ini menggunakan bantuan perangkat lunak komputer dengan urutan sebagai berikut :

1. Pengambilan Data

2. Plot Data

3. Pemeriksaan Kestasioneran

4. Identifikasi Model

5. Penaksiran Parameter

6. Penentuan Persamaan Model

7. Verifikasi Model

8. Validasi Model

9. Prediksi

\section{Hasil Dan Pembahasan \\ 3.1. Plot Data Harga Bulanan Cengkeh, Kopra, dan Pala}

Berdasarkan plot data pada gambar 1 menunjukkan harga cengkeh berkisar antara Rp90.000,oo hingga Rp140.000,o0. Fluktuasi pola data menggambarkan adanya fluktuasi harga yang secara keseluruhan memiliki kecenderungan harga naik turun, harga terendah cengkeh adalah Rp89.000,00/kg dicapai pada bulan November 2018, kemudian harga cengkeh tertinggi yaitu sebesar Rp138.458,0o/kg yang dicapai pada bulan Januari 2015. Selanjutnya dari bulan Februari 2016 menurun kembali dan cenderung berfluktuasi sampai pada Maret 2019.

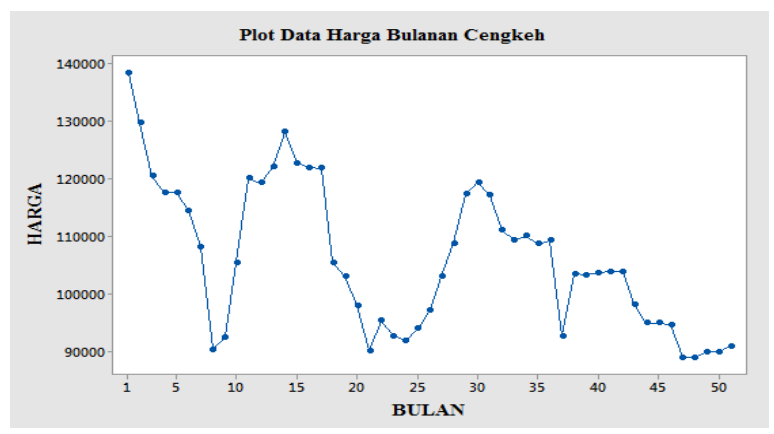

Gambar 1. Plot Data Harga Bulanan Cengkeh Periode Januari 2015 - Maret 2019

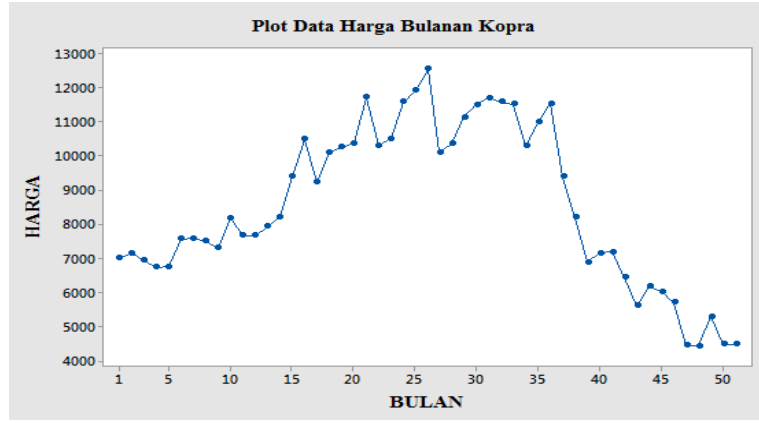

Gambar 2. Plot Data Harga Bulanan Kopra Periode Januari 2015 - Maret 2019

Berdasarkan gambar 2 dari plot data terlihat bahwa harga bulanan kopra berkisar antara Rp4.000,oo hingga Rp13.000,00. Fluktuasi pola data menggambarkan adanya fluktuasi harga yang secara 
keseluruhan memiliki kecenderungan harga naik turun. Dimana harga terendah kopra yaitu Rp4.450,00/kg pada bulan Desember 2018, harga tertinggi kopra mencapai Rp12.550,00/kg pada bulan Februari 2017.

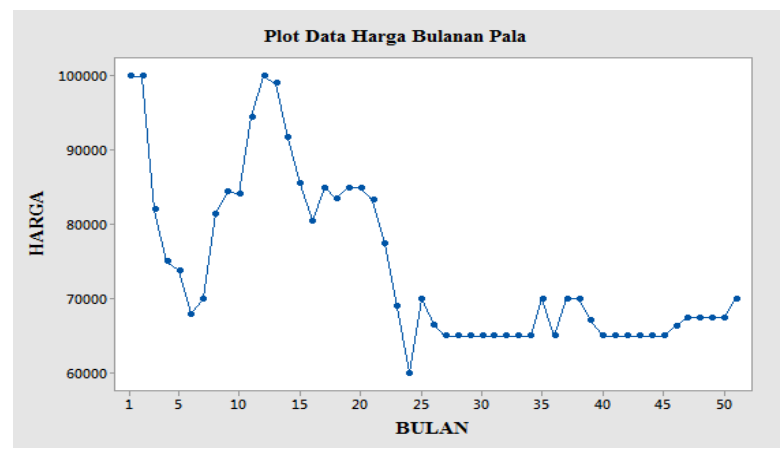

Gambar 3. Plot Data Harga Bulanan Pala Periode

Januari 2015 - Maret 2019

Pada plot data harga pala dalam gambar 3 terlihat bahwa harga bulanan pala berkisar antara Rp60.000,oo hingga Rp100.000,00. Fluktuasi pola data menggambarkan adanya fluktuasi harga yang secara keseluruhan memiliki kecenderungan harga naik turun. Dimana harga terendah pala yaitu Rp60.000,oo/kg yaitu pada bulan Desember 2016, dan harga tertinggi pala sebesar Rp100.000,00/kg pada bulan Januari 2015 .

\subsection{Uji Kestasioneran Data}

\subsubsection{Uji Akar Unit (unit root test)}

a. Harga Cengkeh

Berikut adalah uji akar unit untuk harga cengkeh:

Null Hypothesis: CENGKEH has a unit root

Exogenous: Constant

Lag Length: 0 (Automatic - based on SIC, maxlag $=10$ )

\begin{tabular}{lccc}
\hline \hline & t-Statistic & Prob. \\
\hline \hline Augmented Dickey-Fuller test statistic & -2.659192 & 0.0884 \\
\hline Test critical values: $\quad$ 1\% level & -3.568308 & \\
& $5 \%$ level & -2.921175 & \\
& $10 \%$ level & -2.598551 & \\
\hline \hline
\end{tabular}

*MacKinnon (1996) one-sided p-values.

\section{Gambar 4. Uji Akar Unit Harga Cengkeh}

Hasil akar unit dapat dilihat berdasarkan uji hipotesis sebagai berikut:

$\mathrm{H}_{0}$ : Cengkeh memiliki akar unit (data tidak stasioner)

$\mathrm{H}_{1}$ : Cengkeh tidak memiliki akar unit (data stasioner) $\alpha=0,05$

Berdasarkan hasil output gambar 4 menunjukkan bahwa nilai $p$-value $(0,0884)>0,05$ dan nilai ADF (2,659192) > nilai Critical Value MacKinnon (5\%) maka terima $\mathrm{H}_{0}$ artinya cengkeh memiliki akar unit (data tidak stasioner). Oleh karena itu, perlu diuji kembali dengan melakukan proses diferensing satu kali:
Null Hypothesis: D(CENGKEH) has a unit root

Exogenous: Constant

Lag Length: 0 (Automatic - based on SIC, maxlag=10)

\begin{tabular}{lccc}
\hline \hline & t-Statistic & Prob. $^{*}$ \\
\hline \hline Augmented Dickey-Fuller test statistic & -5.804346 & \multirow{2}{*}{0.0000} \\
\hline Test critical values: & 1\% level & -3.571310 & \\
& $5 \%$ level & -2.922449 & \\
& $10 \%$ level & -2.599224 & \\
\hline \hline
\end{tabular}

*MacKinnon (1996) one-sided p-values.

Gambar 5. Diferensing Uji Akar Unit Harga Cengkeh

Dapat dilihat hasil output gambar 5 nilai $p$-value $(0,0000)<0,05$ dan nilai ADF $(-5,804346)<$ nilai Critical Value MacKinnon (5\%) maka tolak $\mathrm{H}_{0}$ artinya cengkeh tidak memiliki akar unit (data stasioner).

\section{b. Harga Kopra}

Berikut adalah uji akar unit untuk harga kopra: Null Hypothesis: KOPRA has a unit root Exogenous: Constant

Lag Length: 0 (Automatic - based on SIC, maxlag=10)

\begin{tabular}{lccc}
\hline \hline & t-Statistic & Prob. $^{*}$ \\
\hline \hline Augmented Dickey-Fuller test statistic & -0.732769 & 0.8288 \\
\hline Test critical values: $\quad 1 \%$ level & -3.568308 & \\
& $5 \%$ level & -2.921175 & \\
& $10 \%$ level & -2.598551 & \\
\hline \hline
\end{tabular}

*MacKinnon (1996) one-sided p-values.

Gambar 6. Uji Akar Unit Harga Kopra

Hasil uji akar unit dapat dilihat berdasarkan uji hipotesis sebagai berikut:

$\mathrm{H}_{0}$ : Kopra memiliki akar unit (data tidak stasioner)

$\mathrm{H}_{1}$ : Kopra tidak memiliki akar unit (data stasioner) $\alpha=0,05$

Berdasarkan hasil output gambar 6 menunjukkan bahwa nilai $p$-value $(0,8288)>0,05$ dan nilai $\mathrm{ADF}$ (-0,732769) > nilai Critical Value MacKinnon (5\%) maka terima $\mathrm{H}_{0}$ artinya kopra memiliki akar unit (data tidak stasioner). Oleh karena itu, perlu diuji kembali dengan melakukan proses diferensing satu kali:

Null Hypothesis: D(KOPRA) has a unit root

Exogenous: Constant

Lag Length: 0 (Automatic - based on SIC, maxlag=10)

\begin{tabular}{lccc}
\hline \hline & t-Statistic & Prob. $^{*}$ \\
\hline \hline Augmented Dickey-Fuller test statistic & -7.318317 & 0.0000 \\
\hline Test critical values: & $1 \%$ level & -3.571310 & \\
& $5 \%$ level & -2.922449 & \\
& $10 \%$ level & -2.599224 & \\
\hline \hline
\end{tabular}

*MacKinnon (1996) one-sided p-values.

Gambar 7. Diferensing Uji Akar Unit Harga Kopra

Dapat dilihat hasil output gambar 7 menunjukkan nilai $p$-value $(0,0000)<0,05$ dan nilai ADF $(-7,318317)<$ nilai Critical Value MacKinnon (5\%) maka tolak $\mathrm{H}_{0}$ artinya kopra tidak memiliki akar unit (data stasioner).

c. Harga Pala

Berikut adalah uji akar unit untuk harga pala: 
Null Hypothesis: PALA has a unit root Exogenous: Constant

Lag Length: 0 (Automatic - based on SIC, maxlag $=10$ )

\begin{tabular}{lccc}
\hline \hline & t-Statistic & Prob. $^{*}$ \\
\hline \hline \multicolumn{2}{l}{ Augmented Dickey-Fuller test statistic } & -2.477368 & 0.1270 \\
\hline Test critical values: $\quad 1 \%$ level & -3.568308 & \\
& $5 \%$ level & -2.921175 & \\
& $10 \%$ level & -2.598551 & \\
\hline \hline
\end{tabular}

*MacKinnon (1996) one-sided p-values.

Gambar 8. Uji Akar Unit Harga Pala

Hasil uji akar unit dapat dilihat berdasarkan uji hipotesis sebagai berikut:

$\mathrm{H}_{0}$ : Pala memiliki akar unit (data tidak stasioner)

$\mathrm{H}_{1}$ : Pala tidak memiliki akar unit (data stasioner)

$\alpha=0,05$

Berdasarkan hasil output gambar 8 menunjukkan bahwa nilai $p$-value $(0,1270)>0,05$ dan nilai $\mathrm{ADF}$ $(-2,477368)>$ nilai Critical Value MacKinnon (5\%) maka terima $\mathrm{H}_{0}$ artinya pala memiliki akar unit (data tidak stasioner). Oleh karena itu, perlu diuji kembali dengan melakukan proses diferensing satu kali:

Null Hypothesis: D(PALA) has a unit root

Exogenous: Constant

Lag Length: 0 (Automatic - based on SIC, maxlag=10)

\begin{tabular}{lccc}
\hline \hline & & t-Statistic & Prob. \\
\hline \hline Augmented Dickey-Fuller test statistic & -5.591950 & 0.0000 \\
\hline Test critical values: & $1 \%$ level & -3.571310 & \\
& $5 \%$ level & -2.922449 & \\
& $10 \%$ level & -2.599224 & \\
\hline \hline
\end{tabular}

*MacKinnon (1996) one-sided p-values.

Gambar 9. Diferensing Uji Akar Unit Harga Pala

Dapat dilihat hasil output gambar 9 menunjukkan nilai $p$-value $(0,0000)<0,05$ dan nilai ADF $\quad(-5,591950)<$ nilai Critical Value MacKinnon (5\%) maka tolak $\mathrm{H}_{0}$ artinya pala tidak memiliki akar unit (data stasioner) [8].

\subsection{Identifikasi Model}

Setelah data diketahui sudah stasioner, tahap selanjutnya ialah menentukan panjang lag optimal yang akan digunakan dalam model VAR. Pemilihan kriteria yang dapat digunakan untuk menentukan orde VAR yaitu dengan melihat nilai AIC (Akaike's Information Criterion) terkecil pada beberapa orde model. Berikut ini hasil penentuan panjang lag optimal dengan menggunakan software EViews dan hasilnya dapat dilihat pada Tabel 2:

Tabel 2. Panjang lag optimal

\begin{tabular}{cc}
\hline Lag & AIC \\
\hline o & 61,01073 \\
$\mathbf{1}$ & $\mathbf{5 6 , 4 5 4 5 8}^{*}$ \\
2 & 56,65050 \\
3 & 56,58018 \\
4 & 56,82917 \\
5 & 56,94755 \\
\hline
\end{tabular}

Berdasarkan output yang disajikan dalam bentuk tabel 2 menunjukan bahwa nilai AIC terkecil adalah 56,45458 diantara berbagai lag yang diajukan yaitu berada pada lag-1 yang berarti bahwa lag optimal ialah lag ke-1. Sehingga dapat diduga pada tahap identifikasi model diperoleh model sementara yang sesuai adalah VAR orde-1 tau VAR(1).

\subsection{Penentuan Parameter Var}

Pada pengujian sebelumnya diperoleh panjang lag optimal yaitu lag ke-1 dimana nilai AIC yang terkecil ialah 56,45458. Penentuan parameter untuk model harga cengkeh, kopra, dan pala yang diolah dengan menggunakan software EViews diperoleh hasil:

Adapun bentuk persamaan dari model VAR orde-1 atau VAR(1) ialah:

$Z_{1, t}=C+\phi_{11} Z_{1, t-1}+\phi_{12} Z_{2, t-1}+\phi_{13} Z_{3, t-1}$

$Z_{2, t}=C+\phi_{21} Z_{1, t-1}+\phi_{22} Z_{2, t-1}+\phi_{23} Z_{3, t-1}$

$Z_{3, t}=C+\phi_{31} Z_{1, t-1}+\phi_{32} Z_{2, t-1}+\phi_{33} Z_{3, t-1}$

dimana:

$Z_{1, t}=$ harga cengkeh pada waktu $\mathrm{t}$

$Z_{2, t}=$ harga kopra pada waktu $\mathrm{t}$

$Z_{3, t}=$ harga pala pada waktu $\mathrm{t}$

\subsection{Penentuan Persamaan Var}

Dari hasil penentuan parameter selanjutnya akan ditentukan model sementara menggunakan software Eviews 7, dibuat persamaan dari model VAR Orde-1 atau VAR(1) menjadi:

1. Cengkeh

Model VAR orde-1 data harga cengkeh yaitu di Sulawesi Utara adalah sebagai berikut:

$$
\begin{aligned}
& Z_{1, t}-Z_{1, t-1}=-668,620+0,174\left(Z_{1, t-1}-Z_{1, t-2}\right)+ \\
& \quad 0,260\left(Z_{2, t-1}-Z_{2, t-2}\right)+0,151\left(Z_{3, t-1}-Z_{3, t-2}\right) \\
& Z_{1, t}=-668,620+1,174 Z_{1, t-1}-0,174 Z_{1, t-2}+ \\
& \quad 0,260 Z_{2, t-1}-0,260 Z_{2, t-2}+0,151 Z_{3, t-1}- \\
& \quad 0,151 Z_{3, t-2} \\
& \text { Kopra }
\end{aligned}
$$

Model VAR orde-1 data harga kopra yaitu di Sulawesi Utara adalah sebagai berikut:

$$
\begin{gathered}
Z_{1, t}-Z_{1, t-1}=-668,620+0,174\left(Z_{1, t-1}-Z_{1, t-2}\right)+ \\
0,260\left(Z_{2, t-1}-Z_{2, t-2}\right)+0,151\left(Z_{3, t-1}-\right. \\
\left.Z_{3, t-2}\right) \\
Z_{2, t}=-47,889+1,060 Z_{2, t-1}-0,060 Z_{2, t-2}+ \\
0,004 Z_{1, t-1}-0,004 Z_{1, t-2}+0,002 Z_{3, t-1}- \\
0,002 Z_{3, t-2}
\end{gathered}
$$

3. Pala

Model VAR orde-1 data harga pala yaitu di Sulawesi Utara adalah sebagai berikut:

$$
\begin{gathered}
Z_{3, t}-Z_{3, t-1}=-326,072+0,215\left(Z_{3, t-1}-Z_{3, t-2}\right)+ \\
0,105\left(Z_{1, t-1}-Z_{1, t-2}\right)+0,625\left(Z_{2, t-1}-Z_{2, t-2}\right) \\
Z_{3, t}=-326,072+1,215 Z_{3, t-1}-0,215 Z_{3, t-2}+ \\
0,105 Z_{1, t-1}-0,105 Z_{1, t-2}+0,625 Z_{2, t-1}- \\
0,625 Z_{2, t-2}
\end{gathered}
$$

dalam bentuk matriks:

$$
\begin{aligned}
& {\left[\begin{array}{l}
Z_{1, t}-Z_{1, t-1} \\
Z_{2, t}-Z_{2, t-1} \\
Z_{3, t}-Z_{3, t-1}
\end{array}\right]=\left[\begin{array}{c}
-668,620 \\
-47,889 \\
-326,072
\end{array}\right]+} \\
& {\left[\begin{array}{lll}
0,174 & 0,260 & 0,151 \\
0,060 & 0,004 & 0,002 \\
0,215 & 0,105 & 0,625
\end{array}\right]\left[\begin{array}{l}
Z_{1, t-1}-Z_{1, t-2} \\
Z_{2, t-1}-Z_{2, t-2} \\
Z_{3, t-1}-Z_{3, t-2}
\end{array}\right]}
\end{aligned}
$$

\subsection{Verifikasi Model}

Setelah penentuan persamaan, langkah selanjutnya adalah melakukan uji kelayakan model. Uji ini dilakukan untuk mengetahui apakah model telah merepresentasikan data dengan baik. Uji kelayakan ini dilakukan dengan menggunakan correlogram residual 
dari error yang akan ditunjukkan pada gambar 10,11, dan 12.

Berikut pengujian white noise dari data berdasarkan hipotesis:

$\mathrm{H}_{0}$ : Data residual memenuhi syarat white noise

$\mathrm{H}_{1}$ : Data residual belum memenuhi syarat white noise $\alpha=0,05 \%$

Jika $P$-value $<\alpha=0,05$ maka tolak $\mathrm{H}_{0}$ yang dimana data residual belum memenuhi syarat white noise.

Date: 05/11/19 Time: 11:04 Sample: 151 Included observations: 50

\begin{tabular}{|c|c|c|c|c|c|c|}
\hline Autocorrelation & \multicolumn{2}{|c|}{ Partial Correlation } & $\mathrm{AC}$ & \multirow{2}{*}{$\begin{array}{l}\text { PAC } \\
0.001\end{array}$} & \multirow{2}{*}{$\begin{array}{l}\text { Q-Stat } \\
2 \text {.E-05 }\end{array}$} & \multirow{2}{*}{$\begin{array}{l}\text { Prob } \\
0.997\end{array}$} \\
\hline ' & 1 & & 0.00 & & & \\
\hline & ' & & & & & \\
\hline id & i & & -0.02 & -0.020 & 0.1956 & 0.978 \\
\hline & $: \%$ & & $\begin{aligned}-0.10 \\
0.06\end{aligned}$ & $\begin{array}{r}-0.106 \\
0.059\end{array}$ & $\begin{array}{l}0.7841 \\
0.9941\end{array}$ & $\begin{array}{l}0.941 \\
0.963\end{array}$ \\
\hline & i & (5) & $\begin{array}{l}0.06 \\
0.05\end{array}$ & $\begin{array}{l}0.059 \\
0.042\end{array}$ & $\begin{array}{l}0.9941 \\
1.1641\end{array}$ & $\begin{array}{l}0.963 \\
0.979\end{array}$ \\
\hline 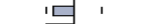 & 다 & & -0.22 & -0.225 & 4.1868 & 0.758 \\
\hline 맘 & 四 & & -0.29 & -0.312 & 9.3773 & \\
\hline 1 다 & '다 & & -0.18 & -0.242 & & 0.2 \\
\hline $1 \mathrm{p}$ & in & $10 \mathrm{C}$ & 0.04 & & & 0.3 \\
\hline i' & 15 & 11 & 0.00 & & & \\
\hline 局 & 口: & $\begin{array}{l}12 \\
13 \\
3\end{array}$ & $\begin{array}{l}0.06 \\
0.11\end{array}$ & $\begin{array}{r}-0.013 \\
0.132\end{array}$ & $\begin{array}{l}11.865 \\
12.798\end{array}$ & $\begin{array}{l}0.457 \\
0.464\end{array}$ \\
\hline & & 14 & 0.00 & 0.036 & 12.800 & \\
\hline b' & ' & 15 & 0.04 & -0.077 & & \\
\hline 曰 & & 16 & 0.17 & 0.0 & & 0 \\
\hline b & & $\begin{array}{l}17 \\
18\end{array}$ & $\begin{array}{l}0.03 \\
0.04\end{array}-34$ & & & 0.6 \\
\hline 巴 i & & 18 & 0.04 & & & 6.6 \\
\hline : & : & $\begin{array}{l}15 \\
20\end{array}-3-3$ & $\begin{array}{l}0.12 \\
-0.19\end{array}$ & $\begin{array}{r}0.154 \\
-0.077\end{array}$ & $\begin{array}{l}16.774 \\
19.922\end{array}$ & $\begin{array}{l}0.6 \mathrm{c} \\
0.4\end{array}$ \\
\hline 1 & & & & -0.060 & 21.479 & 0.43 \\
\hline 1 & & 23 & & -0.0 & 21.620 & 0.4 \\
\hline & ' & 23 & & -0.036 & 22.058 & 0.5 \\
\hline & 1 & 24 & 0.07 & 0.096 & 22.660 & 0.540 \\
\hline
\end{tabular}

Gambar 10. Correlogram residual cengkeh

Berdasarkan gambar 10 correlogram residual model untuk harga cengkeh terlihat semua lag residual dari lag-1 sampai lag-24 nilai probabilitasnya lebih dari alpha 0,05 dengan kata lain $\mathrm{H}_{0}$ diterima yang berarti data residual memenuhi syarat white noise.

Berdasarkan gambar 11 correlogram residual model untuk harga kopra terlihat bahwa semua lag residual dari lag-1 sampai lag-24 nilai probabilitasnya lebih dari alpha 0,05 dengan kata lain $\mathrm{H}_{0}$ diterima yang berarti data residual memenuhi syarat white noise.

\begin{tabular}{|c|c|c|c|c|c|c|c|}
\hline Autocorrelation & Partial Co & orrelation & & $A C$ & PAC & Q-Stat & Prob \\
\hline 1 & & 1 & 1 & -0.011 & -0.011 & 0.0065 & 0.936 \\
\hline & ic & i & 2 & -0.151 & -0.151 & 1.2380 & 0.538 \\
\hline 171 & $1]$ & 1 & 3 & 0.024 & 0.021 & 1.2710 & 0.736 \\
\hline 161 & 1 & 1 & 4 & 0.053 & 0.032 & 1.4302 & 0.839 \\
\hline ( & & 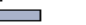 & 5 & 0.429 & 0.448 & 12.081 & 0.034 \\
\hline$1 \longdiv { 1 }$ & i & 1 & 6 & -0.022 & 0.006 & 12.111 & 0.060 \\
\hline 10 & i & i & 7 & -0.111 & 0.022 & 12.861 & 0.076 \\
\hline 17 & & 1 & 8 & 0.045 & -0.014 & 12.983 & 0.112 \\
\hline & & i & 9 & 0.024 & -0.035 & 13.021 & 0.162 \\
\hline : 口 & i & ב & 10 & 0.272 & 0.119 & 17.819 & 0.058 \\
\hline & i & i & 11 & 0.040 & 0.074 & 17.926 & 0.083 \\
\hline 10 & $i$ & 1 & 12 & -0.056 & 0.063 & 18.137 & 0.112 \\
\hline 18 & 1드 & & 13 & -0.108 & -0.182 & 18.963 & 0.124 \\
\hline 11 & & & 14 & -0.025 & -0.080 & 19.009 & 0.165 \\
\hline 1 1 & & & 15 & 0.121 & -0.120 & 20.096 & 0.168 \\
\hline 151 & & & 16 & 0.043 & 0.022 & 20.235 & 0.210 \\
\hline & 10 & & 17 & -0.094 & -0.054 & 20.938 & 0.229 \\
\hline & & & 18 & $\begin{array}{l}-0.154 \\
-0.155\end{array}$ & $\begin{array}{l}-0.064 \\
-0.061\end{array}$ & 22.899 & 0.195 \\
\hline 17 & 10 & & 19 & -0.065 & -0.105 & 23.256 & 0.226 \\
\hline יו & 4 & & 20 & 0.206 & 0.135 & 26.916 & 0.138 \\
\hline 161 & 맘 & & 21 & -0.142 & -0.232 & 28.712 & 0.121 \\
\hline i늠 & 只 & i & 22 & -0.204 & -0.120 & 32.571 & 0.068 \\
\hline 1 & 1 & 1 & 23 & -0.034 & 0.039 & 32.683 & 0.087 \\
\hline 10 & 10 & 1 & 24 & -0.115 & -0.099 & 33.995 & 0.085 \\
\hline
\end{tabular}

Gambar 11. Correlogram residual kopra

\begin{tabular}{|c|c|c|c|c|c|c|}
\hline Autocorrelation & Partial Correlation & & AC & PAC & Q-Stat & Prob \\
\hline 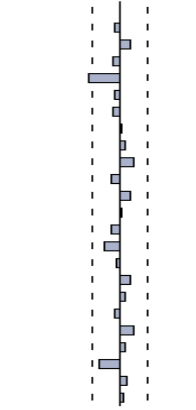 & 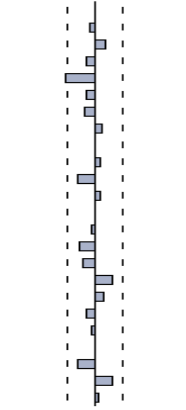 & \begin{tabular}{|r}
1 \\
2 \\
3 \\
4 \\
5 \\
6 \\
7 \\
8 \\
9 \\
10 \\
11 \\
12 \\
13 \\
14 \\
15 \\
16 \\
17 \\
18 \\
19 \\
20 \\
21 \\
22 \\
23 \\
24
\end{tabular} & $\begin{array}{r}0.004 \\
-0.058 \\
0.105 \\
-0.080 \\
-0.323 \\
-0.058 \\
-0.079 \\
0.019 \\
0.050 \\
0.134 \\
-0.096 \\
0.099 \\
0.0112 \\
-0.097 \\
-0.171 \\
-0.037 \\
0.110 \\
0.057 \\
-0.062 \\
0.139 \\
0.061 \\
-0.212 \\
0.072 \\
0.031\end{array}$ & $\begin{array}{r}0.004 \\
-0.058 \\
0.105 \\
-0.086 \\
-0.315 \\
-0.085 \\
-0.109 \\
0.072 \\
0.008 \\
0.052 \\
-0.181 \\
0.0447 \\
0.001 \\
-0.034 \\
-0.167 \\
-0.133 \\
0.174 \\
0.088 \\
-0.089 \\
-0.045 \\
0.002 \\
-0.187 \\
0.178 \\
0.030\end{array}$ & $\begin{array}{l}0.0009 \\
0.1827 \\
0.7876 \\
1.1450 \\
7.1690 \\
7.3693 \\
7.7496 \\
7.7729 \\
7.9319 \\
9.0928 \\
9.7011 \\
10.373 \\
10.384 \\
11.061 \\
13.233 \\
13.337 \\
14.289 \\
14.557 \\
14.878 \\
16.560 \\
16.889 \\
21.050 \\
21.554 \\
21.649\end{array}$ & $\begin{array}{l}0.975 \\
0.913 \\
0.852 \\
0.887 \\
0.208 \\
0.288 \\
0.355 \\
0.456 \\
0.541 \\
0.523 \\
0.557 \\
0.583 \\
0.662 \\
0.681 \\
0.584 \\
0.648 \\
0.647 \\
0.692 \\
0.730 \\
0.681 \\
0.718 \\
0.518 \\
0.547 \\
0.600\end{array}$ \\
\hline
\end{tabular}

Gambar 12. Correlogram residual pala

Berdasarkan gambar 12 correlogram residual model untuk harga pala terlihat bahwa semua lag residual dari lag-1 sampai lag-24 nilai probabilitasnya lebih dari alpha 0,05 dengan kata lain $\mathrm{H}_{0}$ diterima yang berarti data residual memenuhi syarat white noise.

\subsection{Validasi Model}

Dalam uji validasi model ini dapat dilakukan dengan membandingkan kondisi data dari ketiga harga cengkeh, kopra, dan pala tersebut untuk mengetahui kondisi data sebenarnya (aktual) dengan data prediksi. Validasi model VAR(1) dari bulan Januari 2015 sampai dengan bulan Maret 2019 dapat ditunjukkan pada gambar berikut:

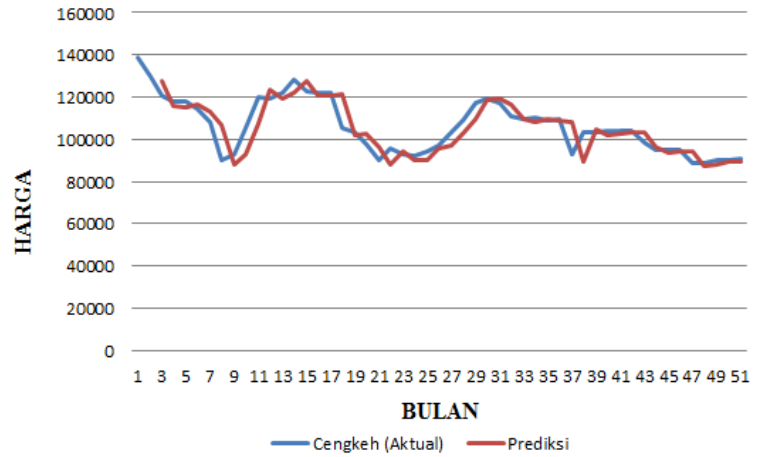

Gambar 13. Data Harga Bulanan Cengkeh sebenarnya (aktual) dan prediksi

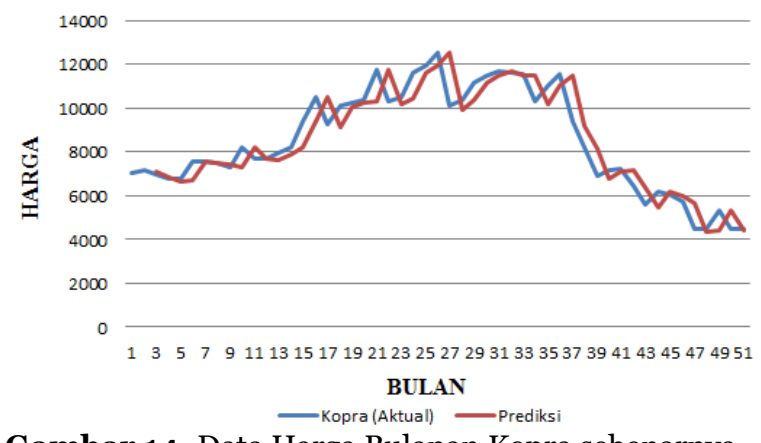

Gambar 14. Data Harga Bulanan Kopra sebenarnya (aktual) dan prediksi 


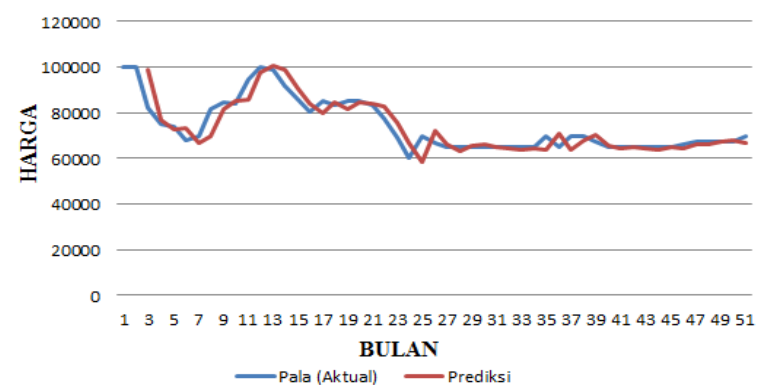

Gambar 15. Data Harga Bulanan Pala sebenarnya (aktual) dan prediksi

Pada gambar 13, gambar 14, dan gambar 15 dapat terlihat bahwa dari bulan Januari 2015 sampai terakhir bulan Maret 2019 data sebenarnya tidak berbeda jauh dengan hasil prediksi. Dengan demikian model VAR Orde-1 bisa digunakan untuk memprediksi harga cengkeh, kopra dan pala pada beberapa bulan ke depan.

\subsection{Prediksi}

Langkah terakhir dalam analisis VAR adalah prediksi. Dalam penelitian ini akan diprediksi untuk periode 3 bulan. Hasil prediksi menggunakan model VAR(1) untuk harga cengkeh, kopra, dan pala di kota Manado yang dituangkan pada tabel 3:

Tabel 3. Hasil Prediksi Harga Bulanan Cengkeh,Kopra, dan Pala di Sulawesi Utara pada Bulan April 2019 sampai dengan Juni 2019

\begin{tabular}{ccccc}
\hline No & Bulan/Tahun & $\begin{array}{c}\text { Prediksi } \\
\text { Cengkeh }\end{array}$ & $\begin{array}{c}\text { Prediksi } \\
\text { Kopra }\end{array}$ & $\begin{array}{c}\text { Prediksi } \\
\text { Pala }\end{array}$ \\
\hline 1 & April 2019 & 90882 & 4461 & 70316 \\
2 & Mei 2019 & 90231 & 4411 & 70021 \\
3 & Juni 2019 & 89392 & 4356 & 69532 \\
\hline
\end{tabular}

Hasil prediksi untuk harga cengkeh, kopra, dan pala di Sulawesi Utara mulai dari periode bulan April 2019 sampai dengan bulan Juni 2019 yaitu pada bulan April 2019 ketiga harga tersebut mengalami kenaikan harga. Pada bulan April 2019 harga cengkeh sebesar Rp90.882,00 harga kopra sebesar Rp4.461,00 dan harga pala sebesar Rp70.316,oo. Pada bulan Mei 2019 harga cengkeh sebesar Rp90.231,00 harga kopra sebesar Rp4.411,00 dan harga pala sebesar Rp70.021,00. Pada bulan Juni 2019 harga cengkeh sebesar Rp89.392,oo harga kopra sebesar Rp4.356,00 dan harga pala sebesar Rp69.532,00.

\section{Penutup}

\subsection{Kesimpulan}

Berdasarkan hasil yang diperoleh maka dapat disimpulkan bahwa:

1. Model Vector Autoregressive (VAR) untuk memprediksi harga cengkeh, kopra, dan pala di Sulawesi Utara menggunakan data bulanan mulai periode Januari 2015 sampai dengan Maret 2019 diperoleh model VAR(1) yang dipilih dari nilai AIC terkecil, dengan persamaan:

$$
\begin{aligned}
Z_{1, t}= & -668,620+1,174 Z_{1, t-1}-0,174 Z_{1, t-2}+ \\
& 0,260 Z_{2, t-1}-0,260 Z_{2, t-2}+0,151 Z_{3, t-1}- \\
& 0,151 Z_{3, t-2}
\end{aligned}
$$

$$
\begin{aligned}
Z_{2, t}= & -47,889+1,060 Z_{2, t-1}-0,060 Z_{2, t-2}+ \\
& 0,004 Z_{1, t-1}-0,004 Z_{1, t-2}+0,002 Z_{3, t-1}- \\
& 0,002 Z_{3, t-2} \\
Z_{3, t}= & -326,072+1,215 Z_{3, t-1}-0,215 Z_{3, t-2}+ \\
& 0,105 Z_{1, t-1}-0,105 Z_{1, t-2}+0,625 Z_{2, t-1}- \\
& 0,625 Z_{2, t-2}
\end{aligned}
$$

2.Prediksi untuk harga cengkeh, kopra, dan pala di Sulawesi Utara bulan April 2019 harga cengkeh sebesar Rp9o.882,00 harga kopra sebesar Rp4.461,oo dan harga pala sebesar Rp70.316,00 bulan Mei 2019 harga cengkeh sebesar Rp90.231,00 harga kopra sebesar Rp4.411,00 dan harga pala sebesar Rp70.021,00 dan bulan Juni 2019 harga cengkeh sebesar Rp89.392,00 harga kopra sebesar Rp4.356,00 dan harga pala sebesar Rp69.532,oo.

\subsection{Saran}

Berdasarkan hasil penelitian yang telah dilakukan, Model Vector Autoregressive (VAR) cukup baik untuk digunakan dalam memprediksi harga cengkeh, kopra, dan pala di Sulawesi Utara. Oleh karena itu, hendaklah pemerintah lebih menganalisa lagi apa yang menjadi faktor-faktor penyebab terjadinya fluktuasi pada harga komoditas cengkeh, kopra, dan pala.

\section{REFERENS}

[1] Tambun, N., S.Palar., dan W.Rompas. 2014. Analisis Struktur Dan Kinerja Ekspor Komoditas Pertanian Pasca Krisis Ekonomi Di Sulawesi Utara. Jurnal Berkala Ilmiah Efisiensi. Vol.14(3). Hal. 83-84.

[2] Lasulika, M.E. 2017. Prediksi Harga Komoditi Jagung menggunakan K-NN Dan Particle Swarm Optimazation Sebagai Fitur Seleksi. Jurnal Ilmiah. Vol.9(3). Hal. 233-234.

[3] Nainggolan, N. 2009. Model Time Series Heteroskedastik. UNPAD Press. Bandung.

[4] Makridakis, S.G., Wheelright, S.G., and Hyndman, R.J. 1993. Forcasting : Methods and Applications. Jhon wilet and sons Inc., USA.

[5] Nainggolan, N. 2011. Pengembangan Model GSTAR dengan Galat ARCH dan Penerapannya pada Inflasi. [disertai] UNPAD, Bandung.

[6] Mulyana, 2004. Buku Ajar Analisis Deret Waktu. Universitas Padjajaran FMIPA Jurusan Statistika, Bandung.

[7] Wei, W.W.S. 1990. Time Series Analysis: Univariate and Multivariate Methods. AddisonWesley Publishing Company, USA.

[8] Sumihi, D., J. S. Kekenusa, dan N. Nainggolan. 2017. Prediksi Tinggi Gelombang Laut Di Perairan Laut Sulawesi Utara Dengan Menggunakan Model Vector Autoregressive (VAR). MIPA Unsrat Online. Vol. 6(2). Hal. 7578. 
Penerapan Model Vector Autoregressive (VAR) Untuk Memprediksi Harga Cengkeh, Kopra dan Pala di Sulawesi Utara

d'Cartesian : Jurnal Matematika dan Aplikasi, Vol. 8 No. 2 (September 2019): 100-107

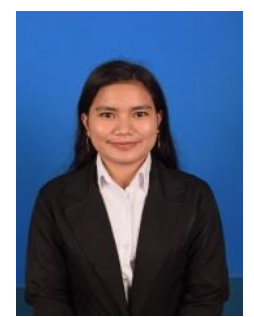

Yulin Tunang

(yulintunang97@gmail.com)

Lahir di Dampilis, Sulawesi Utara

pada tanggal o8 Juli 1997.

Menempuh pendidikan tinggi

Jurusan Matematika, FMIPA,

Universitas Sam Ratulangi Manado.

Tahun 2019 adalah tahun terakhir ia menempuh studi. Makalah ini merupakan hasil penelitian skripsinya yang dipublikasikan.

Tohap Manurung (Tohapm@unsrat.ac.id)

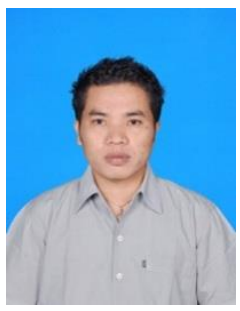

Lahir pada tanggal 24 Desember 1979. Pada tahun 2003 mendapatkan gelar Sarjana Sains (S.Si) yang diperoleh dari Universitas Sumatera Utara. Gelar Magister Sains diperoleh dari Institut Teknologi Bandung pada tahun 2010. Ia bekerja di UNSRAT di Program Studi Matematika sebagai pengajar akademik tetap UNSRAT.

Nelson Nainggolan (n-nelson@unsrat.ac.id)

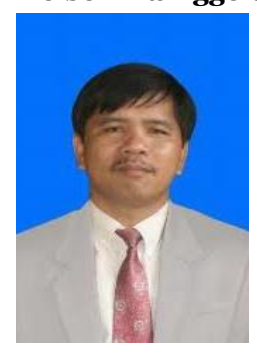

Lahir di Tapanuli Utara tanggal 9 Maret 1967. Gelar sarjana pendidikan Matematika diperoleh tahun 1992 di FMIPA IKIP Negeri Medan. Tahun 1996 menyelesaikan studi S2, di jurusan Matematika ITB Bandung. Tahun 2011 menyelesaikan studi S3 pada bidang Matematika di Universitas Padjadjaran Bandung. Saat ini menjadi pengajar akademik tetap di jurusan Matematika FMIPA Unsrat Manado. 